\title{
Potential methane production and oxidation along the soil chronosequence of the Rotmoos glacier forefield
}

\section{Potenzielle Methanproduktion und -oxidation von Böden entlang der Chronosequenz des Rotmooser Gletschervorfelds}

\author{
Eva Maria Prem ${ }^{1 *}$, Nadine Praeg ${ }^{1}$, Katrin Hofmann ${ }^{1}$, Andreas Otto Wagner ${ }^{1}$, Paul Illmer ${ }^{1}$ \\ ${ }^{1}$ Department of Microbiology, Universität Innsbruck, Technikerstraße 25d, 6020 Innsbruck, Austria \\ * Corresponding author: eva.prem@uibk.ac.at
}

Received: 20 September 2018, received in revised form: 14 January 2019, accepted: 16 January 2019

\begin{abstract}
Summary
Five differently developed soils aged 6, 35, 80, 150, and >5000 years with the same bedrock and the same (current) climate conditions were chosen to assess abiotic and enzymatic properties as well as methanogenic and methanotrophic activities. Most abiotic properties (dry weight, $\mathrm{pH}$, soil organic matter, and ammonium content), enzyme activities (dehydrogenase [DH] activity, ammonification $[A M]$ rate, dimethylsulfoxide reduction), and potential methane oxidation (PoMO) per gram of dry weight (DW) increased with soil age. In contrast, potential methane production (PoMP) as well as the nitrate content per gram of DW and most enzymatic properties per gram of soil organic matter (SOM) did not increase with soil age but reached its maximum in the middleaged soils (80-150 years). Our results show that (i) microbial activity does not consequently increase with SOM content/soil age; (ii) methane production can be measured in undeveloped soils, whereas methane oxidation is more restricted to fully developed soils; and (iii) certain soil modifications (change in water content, ammonium addition) could influence potential methane production/ oxidation. When considering the concurrent release of raw soil because of the melting of perpetual ice, these data could help to better understand and assess the consequences of global change.
\end{abstract}

Keywords: glacier forefield, climate change, Alpine soils, methane production, methane oxidation

\section{Zusammenfassung}

Das Methanproduktions- (PoMP) und das Methanoxidationspotenzial (PoMO) wurde von 5 Böden unterschiedlichen Alters (6, 35, 80, 150 und >5000 Jahre alt) bestimmt und mit abiotischen und biochemischen Bodenparametern in Beziehung gebracht. Die meisten abiotischen (Trockengewicht, $\mathrm{pH}$ - Wert, organische Substanz und Ammoniumgehalt) und enzymatischen Parameter (Dehydrogenaseaktivität, Ammonifikation, Dimethylsulfoxidreduktion) sowie das Methanoxidationspotenzial (pro g Trockengewicht) stiegen mit dem Bodenalter. Das Methanproduktionspotenzial, der Nitratgehalt (pro g Trockengewicht) und die enzymatischen Parameter, bezogen auf $1 \mathrm{~g}$ organische Substanz, waren jedoch in Böden mittleren Alters am höchsten. Die Ergebnisse zeigen, dass I) die mikrobielle Aktivität nicht unbedingt mit der organischen Substanz bzw. mit dem Bodenalter steigt, II) die biologische Methanproduktion bereits in unterentwickelten Böden nachgewiesen werden kann, wohingegen die biologische Methanoxidation eher auf gut entwickelte Böden beschränkt ist und dass III) Bodenmodifikationen (Änderung des Wassergehalts, Ammoniumzugabe) die potenzielle Methanproduktion und -oxidation beeinflussen können. Aufgrund der fortwährenden Freilegung von Rohböden durch das Abschmelzen der Gletscher können diese Daten dazu beitragen, die Konsequenzen des Klimawandels besser zu verstehen und zu beurteilen.

Schlagworte: Gletschervorfeld, Klimawandel, Alpine Böden, Methanproduktion, -oxidation 


\section{Introduction}

Glaciers in the Alps have been retreating since the end of the Little Ice Age in 1850s. As a consequence, differently developed soils of the same bedrock and under same current climate conditions are in immediate proximity and can be used for pedogenesis studies (Tscherko et al., 2004; Nicol et al., 2005; Göransson et al., 2011). In the first colonization step, chemolithotrophic, chemoorganotrophic, and phototrophic microorganisms (Hodkinson et al., 2003; Mapelli et al., 2011; Zumsteg et al., 2012) as well as organic material and invertebrates (Hodkinson et al., 2002) are deposited on the raw/rocky surface, showing that heterotrophic microorganisms colonize recently exposed rocks before autotrophic ones (Tscherko et al., 2003; Bardgett et al., 2007). It can take decades or even centuries before plants can grow on these soils depending on temperature, moisture, and energy supply (Hodkinson et al., 2002). The microbial community structure and the metabolic strategies change steadily but directionally with soil age-from rather unstable but highly reproductive r-strategists to more stable and efficient k-strategists (Garland et al., 2001; Sigler et al., 2002). Besides, the microbial community structure at glacier forelands depends on the age and recalcitrance of the organic material (Bardgett et al., 2007). Enzyme activities are important parameters for describing the metabolic potentials of these microbial communities along the chronosequence (Sigler et al., 2002). In this context, previous studies have shown that enzyme activities per gram of dry weight (DW) tend to increase with soil age (Ulrich et al., 2010; Brankatschk et al., 2011; Hofmann et al., 2013; Zeng et al., 2015).

The chronosequence in the Rotmoos valley is an ideal habitat to also portray the succession of microorganisms engaged in the methane cycle. Methanogenic archaea and methanotrophic microorganisms are responsible for the biological production and oxidation of the greenhouse gas methane, respectively (Le Mer and Roger, 2001). Methanogenic archaea, obligate anaerobes, are able to inhabit aerobic soils (Küsel et al., 1999; Bomberg et al., 2010; Angel et al., 2011; Prem et al., 2014; Hofmann et al., 2016; Praeg et al., 2017; Mutschlechner et al., 2018). Within soils, methanogens presumably survive in anoxic micro niches (Peters and Con$\mathrm{rad}, 1995)$. However, some studies also indicate that methanogens can tolerate certain amounts of oxygen and thus survive oxic periods within the soil (Bomberg et al., 2010).
For a long time, it was believed that methane can only be oxidized in aerobic environments such as upland soils or landfills (Knief et al., 2003; Bohn et al., 2011) or anaerobically in the presence of sulfate in marine environments (Boetius et al., 2000; Orphan et al., 2002; Hinrichs and Boetius, 2003). Recent studies showed that anaerobic oxidation of methane (AOM) can also take place in anaerobic habitats such as peatlands, deep lake sediments, freshwater wetlands, or waste water treatment plants by anaerobic methanotrophic (ANME) archaea or denitrifying anaerobic methane-oxidizing (DAMO) microorganisms (Raghoebarsing et al., 2006; Zhu et al., 2015; Wang et al., 2017). AOM can be linked to a variety of biochemical systems such as the freshwater sulfur cycle (Segarra et al., 2015), electron acceptors such as iron (Sivan et al., 2011) or nitrate (Raghoebarsing et al., 2006; Wang et al., 2017), or to electron shuttles such as humic acids (Blodau and Deppe, 2012).

To our knowledge, only few studies focused on the microbial activity and especially on the activity of methanogens and methanotrophs in underdeveloped soils such as glacier forefields or sub-glacial habitats (Wadham et al., 2008; Bárcena et al., 2010, 2011; Stibal et al., 2012; Hofmann et al., 2013; Chiri et al., 2015). For example, recently exposed soils in Greenland were anoxic because of meltwater and showed an in situ methane release. However, the diversity of methanotrophic microbial communities and the potential $\mathrm{CH}_{4}$ oxidation increased with soil age; and 80 - to 150 -year-old soils were shown to take up methane (Bárcena et al., 2010, 2011). In previous batch experiments, it was shown that soils from the Rotmoos glacier foreland can produce and oxidize methane under certain conditions, thus showing that methanogens and methanotrophs can be present and active at these sites. However, soil age alone could not explain the alterations in potential methane production and oxidation (Hofmann et al., 2013). Compared with the descriptive investigation of Hofmann et al. (2013), we used five soils of different age for an experimental approach. We investigated the effect of different incubation temperatures and water regimens on the potential methane production and oxidation. As $\mathrm{NH}_{4}^{+}$content can have a significant influence on methanogenic archaea and methanotrophic species (Aronson et al., 2012; Prem et al., 2014), a further aim of this study was to investigate the effect of $\mathrm{NH}_{4}^{+}$ addition on the methane cycle. 


\section{Materials and methods}

\subsection{Experimental site and soil sampling}

The study site is located near Obergurgl in the Tyrolean Oetz Valley (Austria) on the glacier forefield of the Rotmoosferner $\left(46^{\circ} 50^{\prime} \mathrm{N}, 11^{\circ} 30^{\prime} \mathrm{E}\right)$ at a sea level of 2,280-2,450 m (Kaufmann, 2001). In 2012, the average annual temperature was $2.5^{\circ} \mathrm{C}$, the sum precipitation was $1,001 \mathrm{~mm}$ in Obergurgl at a sea level of 1,942 m (ZAMG, Zentralanstalt für Meteorologie und Geodynamik, Austria). The parental material mainly consists of paragneis and mica schist (Schwienbacher and Koch, 2010). Further information on climate conditions, bedrock properties, and early succession can be looked up elsewhere (Kaufmann, 2001; Schwienbacher and Koch, 2010; Hofmann et al., 2013). Soil samples aged approximately 6 (S1), 35 (S1A), 80 (S2), 150 (S2A), and $>5,000$ (S3) years (Hofmann et al., 2013) were taken along the chronosequence in autumn 2012. The sampling location $S 1$ is situated at the margin of the glacier, S1A and S2 are situated along the moraine, S2A is situated at the end of the moraine (year 1858), and S3 is situated outside the glacier. $S 3$ is ice free for $>5,000$ years. As the main objective of this study was to experimentally test specific soil modifications along the chronosequence (see Section 2.5), 10 samples were taken in close proximity (about $10 \mathrm{~m}$ ) for each site (S1-S3) and pooled to 1 sample for each site $(5$ samples in total; volume of each sample is about $2 \mathrm{~L}$ ). Each sample was sieved to pass $2-\mathrm{mm}$ mesh and stored at $4^{\circ} \mathrm{C}$ until further analyses. The samples were stored in plastic bags that enabled gas exchange (aerobic conditions) but kept the water loss to a minimum. Owing to the lack of well-developed soil horizons, the samples of soil S1-S2A were taken just beneath the soil ground surface $(-6$ to $-1 \mathrm{~cm})$. The samples of soil S3 were taken beneath the root horizon.

\subsection{Experimental design}

Soils of five different ages along a chronosequence of the Rotmoosferner were used for the investigation. All chemical and enzyme analyses of the soils were performed subsequently after sampling and carried out at least in triplicate. For the assessment of the potential methane production (PoMP) and potential methane oxidation (PoMO), soil samples with varying treatments were prepared as described in Section 2.5. Thus, there were eight treatments including two temperatures $\left(10^{\circ} \mathrm{C}\right.$ and $37^{\circ} \mathrm{C}$ ), two water contents (water saturation and natural water content), and two ammoni- um concentrations (ammonium added, natural ammonium content). For each variant, twice-autoclaved soil samples were also included and treated equally (negative controls). The headspace samples were gas-chromatographically measured after an incubation period of 28 days. This 4 -week incubation period was considered to be sufficient for the growth and activity of microorganisms engaged in the methane cycle, as proven in previous studies (e.g., Wagner et al., 2010). Negative controls were subtracted from the results.

\subsection{Chemical analyses}

All following methods of chemical analyses were performed according to standard protocols described elsewhere (Schinner et al., 1996). DW was determined after the samples were dried at $105^{\circ} \mathrm{C}$ overnight (approximately $16 \mathrm{~h}$ ). SOM content was assessed in dried samples that were incinerated at $430^{\circ} \mathrm{C}$ for $5 \mathrm{~h}$. A temperature of $430^{\circ} \mathrm{C}$ was used to avoid gaseous losses of $\mathrm{CO}_{2}$ out of carbonates. Soil $\mathrm{pH}$ was determined electrochemically in a $0.01 \mathrm{M} \mathrm{CaCl}_{2}$ solution (mixing ratio, 1:12.5). For the measurement of the plant-available ammonium content, $7.5 \mathrm{~g}$ of soil was mixed with $30 \mathrm{~mL}$ of a $2 \mathrm{M} \mathrm{KCl}$ extraction solution. The extracts were filtered and 1:2 diluted with distilled water (except for soils S1) and measured spectrophotometrically in a solution containing $\mathrm{NaOH}$, nitroprusside and dichloroisocyanuric acid sodium salt at a wavelength of $660 \mathrm{~nm}$ (see Section 2.6). Ammonium chloride was used as standard. For the measurement of the nitrate content, $7.5 \mathrm{~g}$ of soil was mixed with $30 \mathrm{~mL}$ of a $2 \mathrm{M} \mathrm{KCl}$ extraction solution. The filtered extracts of soil S1 were 1:10 diluted with distilled water; all other extracts were 1:20 diluted. The $10 \mathrm{~mL}$ of the diluted extract was mixed with $0.4 \mathrm{~mL}$ of sulfuric acid (96\%, 1:10 diluted) and measured at $210 \mathrm{~nm}$ via ultraviolet absorption (see Section 2.6). Potassium nitrate was used as standard. For the blank samples, nitrate was reduced with copper-plated zinc granules.

\subsection{Enzyme analyses}

All following methods of enzyme analyses were performed according to standard protocols described elsewhere (Schinner et al., 1996): Activities of dehydrogenase (DH) were determined by incubating $2.5 \mathrm{~g}$ of each soil sample with $2.5 \mathrm{~mL}$ of triphenyltetrazolium chloride (TTC) in the dark for $16 \mathrm{~h}$. Blank samples were incubated with $0.1 \mathrm{M}$ Tris buffer. The produced triphenylformazan (TPF) was extracted with 12.5 $\mathrm{mL}$ of acetone for $2 \mathrm{~h}$. After filtration, the extracts were 1:2 diluted and measured colorimetrically at $546 \mathrm{~nm}$ within $1 \mathrm{~h}$ 
(see Section 2.6). For the determination of the ammonification (AM) activity, $5 \mathrm{~g}$ of each soil was saturated with $15 \mathrm{~mL}$ of distilled water for 7 days. Blank samples were stored at $-20^{\circ} \mathrm{C}$. After 7 days, $15 \mathrm{~mL}$ of a $2 \mathrm{M} \mathrm{KCl}$ extraction solution was added for $30 \mathrm{~min}$. The filtered extracts were 1:2 ( $\mathrm{S} 1$, blank samples) and 1:10 (S1A-S3) diluted with distilled water. The ammonium released was measured as described earlier. For dimethylsulfoxide (DMSO) analysis, $5 \mathrm{~g}$ of each soil sample was incubated with $1.25 \mathrm{~mL}$ of DMSO in gas-tight flasks at $30^{\circ} \mathrm{C}$ for $4 \mathrm{~h}$. The produced dimethylsulfide (DMS), gaseous at room temperature, was subsequently measured using gas chromatography (see Section 2.6).

\subsection{PoMP and PoMO analyses}

For the assessment of PoMP and PoMO, $10 \mathrm{~g}$ of soil sample (fresh weight) was filled in each sterile serum flask. Besides soil samples with natural ammonium content, soil samples with an ammonium addition of $3.5 \mathrm{~g} \mathrm{NH}_{4}^{+} \mathrm{N}$ $\mathrm{L}^{-1}$ soil solution, based on the results of Lins and Illmer (2012), were also included in the assessment. For that purpose, ammonium chloride (in powder form) was directly added to the soil samples. To simulate snow melt in spring, not only soil samples of in situ moisture but also soil samples under water-saturated conditions were included (addition of sterile, distilled water: $1.2 \mathrm{~mL}$ for $S 1,2.0 \mathrm{~mL}$ for $\mathrm{S} 1 \mathrm{~A}, 3.3 \mathrm{~mL}$ for S2, $4.1 \mathrm{~mL}$ for S2A, and $4.5 \mathrm{~mL}$ for S3). The samples were incubated at $10^{\circ} \mathrm{C}$ and $37^{\circ} \mathrm{C}$ in order to promote psychrophilic and mesophilic microorganisms, respectively. For the assessment of PoMP, the open flasks were evacuated and flushed with sterile $\mathrm{N}_{2} / \mathrm{CO}_{2}$ (70:30) gas for several times. After the last flushing step, the flasks were sealed with sterile rubber stoppers to ensure gas tightness throughout the experiment. For the assessment of PoMO, the infusion flasks were sealed under aerobic conditions and $1 \%$ of the headspace was replaced by methane using a syringe and cannula. A concentration of $1 \% \mathrm{CH}_{4}$ was chosen because of previous research approaches at this study site (Hofmann et al., 2013). Methane concentration in the headspace was measured at the beginning of the experiment and after an incubation period of 4 weeks.

\subsection{Analytical instruments}

The $\mathrm{pH}$ measurements were conducted with a $\mathrm{pH}$ meter and a glass electrode. All colorimetric measurements were carried out using a Hitachi U-2001 Spectrophotometer. For DMS analyses, a Shimadzu GC-2010 gas chromato- graph was used (Wagner et al., 2012); the oven and injector temperature was set to $100^{\circ} \mathrm{C}$ and the flame ionization detector (FID) temperature to $130^{\circ} \mathrm{C}$. Helium gas was used as mobile phase. For methane detection, a Shimadzu GC-2010 Plus gas chromatograph was used as described earlier (Hofmann et al., 2016). The oven temperature was set to $140^{\circ} \mathrm{C}$, the injector temperature to $160^{\circ} \mathrm{C}$, and the FID temperature to $180^{\circ} \mathrm{C}$. Nitrogen gas was used as mobile phase, and hydrogen and compressed air for the FID.

\subsection{Statistical analyses}

Graphical presentations (box plots) and statistical analyses were performed with Statistica $9\left(\mathrm{StatSoft}^{\circledR}\right)$. Normal probability plots with standardized residuals were performed for each parameter. The Shapiro-Wilk W test was used to check normal distribution within each group. The Levene test was used to check for homogeneity of variance. The results of $\mathrm{DH}$ activity, $\mathrm{pH}, \mathrm{NH}_{4}^{+}-\mathrm{N}$ content, and $\mathrm{NO}_{3}^{-}-\mathrm{N}$ content were used for one-way ANOVA $(\mathrm{p}<0.05)$, including Bonferroni post-hoc tests (B-test). The results of DW, SOM, DMSO reduction, AM, and PoMO were further processed with the Mann-Whitney (M-W) U test $(\mathrm{p}<0.05)$ and Kruskal-Wallis (K-W) one-way ANOVA $(\mathrm{p}<0.05)$, including multiple comparisons of mean ranks for all groups by computing p-values with two-sided significance levels and with a Bonferroni adjustment.

\section{Results}

\subsection{Chemical analyses}

All chemical and enzymatic parameters (per gram of DW), including the respective statistical analyses, are given in Table 1. The results of the enzymatic properties per gram of DW as well as per gram of SOM are also presented in Figure 1. SOM content ranged from $0.99 \%( \pm 0.054)$ in S1, the youngest soil, to $11.09 \%( \pm 0.311)$ in S3, the oldest soil. The plant-available ammonium content was also highest in the oldest soil (S3) and reached a value of 9.72 $( \pm 0.134) \mu \mathrm{g} \mathrm{NH}_{4}^{+}-\mathrm{N} \mathrm{g}^{-1} \mathrm{DW}$. $\mathrm{NO}_{3}-\mathrm{N}$ content, on the other hand, was highest in S2A $\left(38.80( \pm 2.658) \mathrm{NO}_{3}^{-}-\mathrm{N}\right.$ $\mathrm{g}^{-1} \mathrm{DW}$ ) and was significantly different (B-test: $\mathrm{p}<0.01$, $\mathrm{n}=3$ ) from younger (S1-S2) and older soils (S3). Slightly acidic conditions were measured in $\mathrm{S} 3$ : $\mathrm{pH} 5.5$ ( \pm 0.04 ). Soils younger than $\mathrm{S} 3$ showed a $\mathrm{pH}$ of around 7 , ranging from $7.1( \pm 0.04)$ in $S 1$ to $6.8( \pm 0.02)$ in S2A. 
Table 1. Chemical and enzymatic properties $(\mathrm{n}=3)$ of the soil S1, S1A, S2, S2A, and S3 presented in mean $(\overline{\mathrm{x}})$ with the respective standard deviation (SD). Letters in brackets show significant differences between the soil samples $(\mathrm{p}<0.05$, one-way ANOVA and Bonferroni post-hoc test for $\mathrm{pH}, \mathrm{NH}_{4}^{+}$content, and $\mathrm{NO}_{3}^{-}$content, and dehydrogenase activity; and Kruskal-Wallis one-way ANOVA with multiple comparisons of mean ranks and Bonferroni adjustment for DW, SOM, ammonification activity, and DMSO reduction).

Tabelle 1. Chemische und enzymatische Parameter $(\mathrm{n}=3)$ der Böden S1, S1A, S2, S2A und S3, als Mittelwert $(\overline{\mathrm{x}})$ mit Standardabweichung (SD) dargestellt. Die Buchstaben in Klammern geben Informationen über signifikante Unterschiede zwischen den Böden ( $p<0.05$, One-way ANOVA mit Bonferroni post-hoc Tests für den pH-Wert, Ammonium- und Nitratgehalt und für die Dehydrogenaseaktivität und Kruskal-Wallis One-way ANOVA mit multiple Mittelwertvergleiche und Bonferroni Korrektur für das Trockengewicht, den Gehalt an organischer Substanz, für die Ammonifikation und DMSO- Reduktion).

\begin{tabular}{|c|c|c|c|c|c|c|c|c|c|}
\hline Soil & & $\begin{array}{l}\text { DW } \\
(\%)\end{array}$ & $\begin{array}{c}\text { SOM } \\
(\%)\end{array}$ & $\mathrm{pH}$ & $\begin{array}{c}\text { Ammonium } \\
\left(\mu \mathrm{g} \mathrm{NH}_{4}^{+}-\mathrm{N} \mathrm{g}^{-1}\right. \\
\mathrm{DW})\end{array}$ & $\begin{array}{c}\text { Nitrate } \\
\left(\mu \mathrm{g} \mathrm{NO}-\mathrm{N} \mathrm{g}^{-1}\right. \\
\mathrm{DW})\end{array}$ & $\begin{array}{c}\text { Dehydrogenase } \\
\text { activity } \\
\left(\mu \mathrm{g} \mathrm{TPF} \mathrm{g}^{-1} \mathrm{DW} \mathrm{h}^{-1}\right)\end{array}$ & $\begin{array}{l}\text { Ammonification activity } \\
\left(\mu \mathrm{g} \mathrm{NH}_{4}^{+} \mathrm{N} \mathrm{g}^{-1}\right. \\
\left.\mathrm{DW} \mathrm{d}^{-1}\right)\end{array}$ & $\begin{array}{l}\text { DMSO reduction } \\
\left(\mu \mathrm{g} \mathrm{DMS} \mathrm{g}^{-1}\right. \\
\left.\mathrm{DW} \mathrm{h}^{-1}\right)\end{array}$ \\
\hline S1 & $\overline{\mathrm{x}}$ & 93.8 (a) & 0.99 (a) & $7.1(\mathrm{~d})$ & 2.30 (a) & 4.97 (a) & 0.90 (a) & 0.75 (a) & 0.47 (a) \\
\hline (6 years) & SD & \pm 0.02 & \pm 0.054 & \pm 0.04 & \pm 0.070 & \pm 0.107 & \pm 0.247 & \pm 0.307 & \pm 0.020 \\
\hline S1A & $\overline{\mathrm{x}}$ & $90.1(a b)$ & $1.71(\mathrm{ab})$ & $7.0(\mathrm{c})$ & 2.46 (a) & $18.80(b)$ & $2.34(\mathrm{~b})$ & $4.57(\mathrm{ab})$ & 2.31 (a) \\
\hline (35 years) & SD & \pm 0.13 & \pm 0.089 & \pm 0.04 & \pm 0.108 & \pm 2.120 & \pm 0.374 & \pm 0.662 & \pm 0.230 \\
\hline S2 & $\bar{x}$ & $84.2(\mathrm{ab})$ & $4.98(a b)$ & 6.9 (b) & 3.98 (b) & $29.00(\mathrm{c})$ & $8.90(\mathrm{~d})$ & $7.83(\mathrm{ab})$ & 6.50 (a) \\
\hline (80 years) & SD & \pm 0.05 & \pm 0.170 & \pm 0.02 & \pm 0.258 & \pm 1.393 & \pm 0.231 & \pm 3.177 & \pm 0.424 \\
\hline S2A & $\overline{\mathrm{x}}$ & $81.3(a b)$ & $5.83(\mathrm{ab})$ & $6.8(b)$ & 4.06 (b) & $38.80(d)$ & $6.10(\mathrm{c})$ & $5.15(\mathrm{ab})$ & 5.81 (a) \\
\hline (150 years) & SD & \pm 0.25 & \pm 0.019 & \pm 0.02 & \pm 0.266 & \pm 2.658 & \pm 0.449 & \pm 1.624 & \pm 0.448 \\
\hline S3 & $\overline{\mathrm{x}}$ & $75.0(b)$ & 11.09 (b) & 5.5 (a) & $9.72(\mathrm{c})$ & $22.47(b)$ & $8.00(\mathrm{~d})$ & $12.00(b)$ & $8.22(\mathrm{a})$ \\
\hline (>5000 years) & $\mathrm{SD}$ & \pm 0.42 & \pm 0.311 & \pm 0.04 & \pm 0.134 & \pm 1.497 & \pm 0.309 & \pm 0.968 & \pm 2.780 \\
\hline
\end{tabular}

\subsection{Enzyme analyses}

The AM activity increased with soil age, ranging from 0.75 ( \pm 0.307$) \mu \mathrm{g} \mathrm{NH}_{4}^{+} \mathrm{N} \mathrm{g}^{-1} \mathrm{DW} \mathrm{d} \mathrm{d}^{-1}$ in soil $\mathrm{S} 1$ to 12.00 $( \pm 0.968) \mu \mathrm{g} \mathrm{NH} \mathrm{NH} \mathrm{g}^{+}-\mathrm{N}^{-1} \mathrm{DW} \mathrm{d}{ }^{-1}$ in soil S3; however, the enzymatic parameter did not increase steadily because there was a slight but statistically not significant decrease in soil S2A compared with soil S2. A slight (but not significant) break in at soil S2A (middle-aged soil) could further be observed when analyzing the DMSO reduction, which ranged from $0.47( \pm 0.02) \mu \mathrm{g}$ DMS g ${ }^{-1} \mathrm{DW} \mathrm{h}^{-1}$ in soil S1 to $8.22( \pm 2.780) \mu \mathrm{g} \mathrm{DMS} \mathrm{g}^{-1} \mathrm{DW} \mathrm{h}^{-1}$ in soil S3. The DH activity significantly increased from soil S1A to S2 (B-test: $\mathrm{p}<0.01, \mathrm{n}=3)$ and reached a value of $8.90( \pm 0.231) \mu \mathrm{g}$ TPF $\mathrm{g}^{-1} \mathrm{DW} \mathrm{h}^{-1}$. Similar to the previous activity parameters, a decrease could be observed from soil S2 to S2A but the decrease in $\mathrm{DH}$ activity was significant (B-test: $\mathrm{p}<0.01, \mathrm{n}=3 ; 6.10( \pm 0.449) \mu \mathrm{g}$ TPF g $\left.{ }^{-1} \mathrm{DW} \mathrm{h}^{-1}\right)$. The oldest soil (S3) only showed the second highest value (8.00 $[ \pm 0.309] \mu \mathrm{g} \mathrm{TPF} \mathrm{g}^{-1} \mathrm{DW} \mathrm{h}^{-1}$ ).

\subsection{PoMP and PoMO analyses}

Samples showed a considerable methane production only at $37^{\circ} \mathrm{C}$ under water-saturated conditions. With the addi- tion of $\mathrm{NH}_{4}^{+}$, S2A (middle-aged soil) showed a PoMP of up to $90.1 \mu \mathrm{L} \mathrm{CH}_{4} \mathrm{~g}^{-1} \mathrm{DW} 28 \mathrm{~d}^{-1}$, followed by $\mathrm{S} 2$ with a PoMP of up to 52.7 and S1A with a PoMP of up to $3.9 \mu \mathrm{L}$ $\mathrm{CH}_{4} \mathrm{~g}^{-1} \mathrm{DW} 28 \mathrm{~d}^{-1}$. Under natural $\mathrm{NH}_{4}^{+}$concentrations, a PoMP of up to $13.1 \mu \mathrm{L} \mathrm{CH}_{4} \mathrm{~g}^{-1}$ DW $28 \mathrm{~d}^{-1}$ could be observed in S2. The youngest (S1) and oldest (S3) soil showed no PoMP at all (Figure 2). When summarizing the data, however, it becomes apparent that the values between the parallel flasks differ distinctly $\left(\mathrm{S} 2 \mathrm{~A}\right.$, with $\mathrm{NH}_{4}^{+}$addition: $30.7 \pm 51.4$; $\mathrm{S} 2$, with $\mathrm{NH}_{4}^{+}$addition: $17.8 \pm 30.3$; $\mathrm{S} 2$, no $\mathrm{NH}_{4}{ }^{+}$addition: $4.5 \pm 7.4 ; \mathrm{S} 1 \mathrm{~A}$, with $\mathrm{NH}_{4}{ }^{+}$addition: $1.3 \pm 2.3 \mu \mathrm{L} \mathrm{CH}_{4} \mathrm{~g}^{-1}$ DW $\left.28 \mathrm{~d}^{-1}\right)$. Owing to these high differences between the parallels and few methane production results, further parametric and non-parametric statistical analyses are not appropriate for the PoMP results, although the differences in PoMP were quite obvious.

The highest PoMO values could be observed in the oldest soil (S3) at $10^{\circ} \mathrm{C}$ and under natural $\mathrm{NH}_{4}^{+}$content: under water-saturated conditions, a mean PoMO of -18.6 $\pm 0.12 \mu \mathrm{L} \mathrm{CH}_{4} \mathrm{~g}^{-1}$ DW $28 \mathrm{~d}^{-1}$ was measured; under natural water conditions, a mean PoMO of $-10.2 \pm 0.44 \mu \mathrm{L}$ $\mathrm{CH}_{4} \mathrm{~g}^{-1} \mathrm{DW} 28 \mathrm{~d}^{-1}$ could be observed (Figure 3 ). At $37^{\circ} \mathrm{C}$, under water-saturated and natural $\mathrm{NH}_{4}^{+}$content conditions, soil S3 showed a PoMP of $-6.3 \pm 0.44 \mu \mathrm{L} \mathrm{CH}_{4} \mathrm{~g}^{-1}$ DW $28 \mathrm{~d}^{-1}$. Soil age had a highly significant influence on 

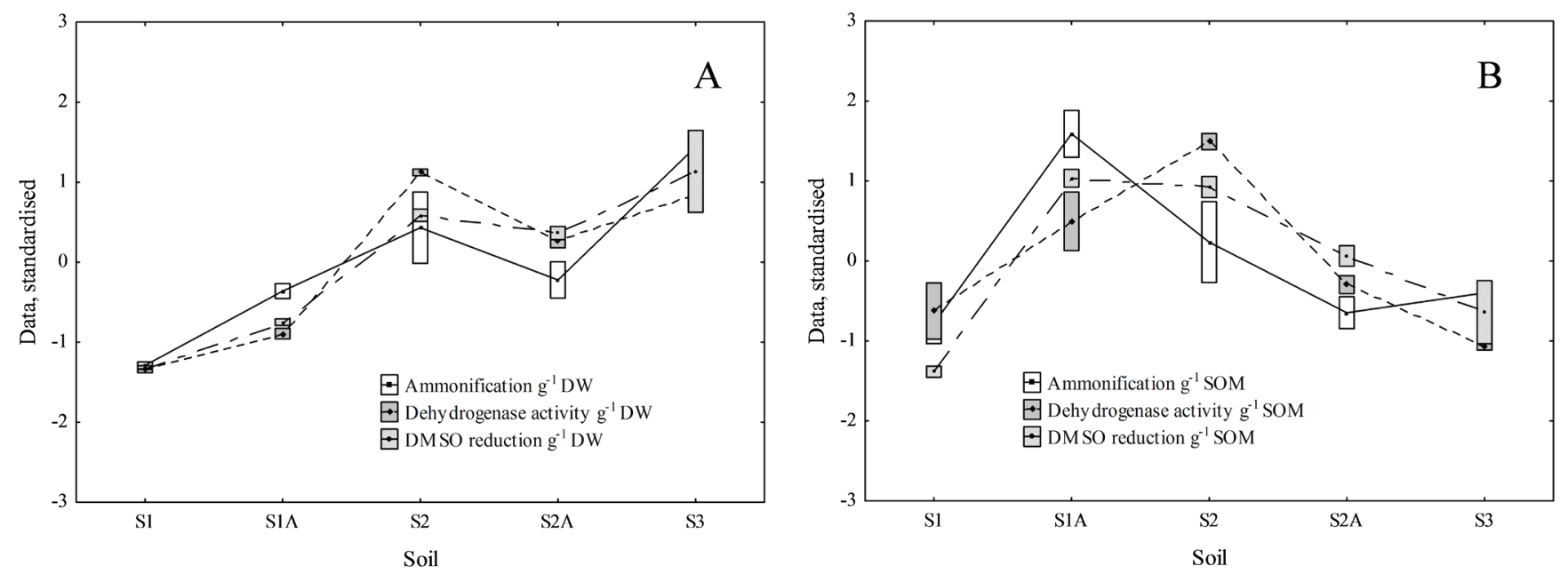

Figure 1. Enzyme activities (activities of dehydrogenase, ammonification, and DMSO reduction) along the chronosequence ( $\mathrm{n}=3$ ). Data were standardized $\left(z=\frac{x-\mu}{\sigma}\right)$. (a) Enzyme parameters calculated per gram of DW, (b) enzyme parameters calculated per gram of SOM. Boxes represent means \pm standard error and markers mean values.

Abbildung 1. Enzymatische Parameter (Dehydrogenaseaktivität, Ammonifikation und DMSO Reduktion) entlang der Chronosequenz $(\mathrm{n}=3)$. Die Daten wurden standardisiert $\left(\mathrm{z}=\frac{\mathrm{x}-\mu}{\sigma}\right)$. A) Enzymatische Daten, bezogen auf $1 \mathrm{~g}$ Trockengewicht (DW), B) enzymatische Daten, bezogen auf $1 \mathrm{~g}$ organische Substanz (SOM). Die Boxen repräsentieren den jeweiligen Mittelwert \pm Standardfehler, die Marker geben Mittelwerte an.

PoMO (K-W: $\mathrm{p}<0.01, \mathrm{n}=24)$, meaning that the oldest soil (S3) is significantly different from all other soils. The incubation temperature also had a significant influence on the methane oxidation (M-W: two-sided $\mathrm{p}<0.05, \mathrm{n}=60$ ), meaning that $\mathrm{PoMO}$ was basically higher at $10^{\circ} \mathrm{C}$ than at $37^{\circ} \mathrm{C}$. Overall, the influence of the $\mathrm{NH}_{4}^{+}$content was not significant $(n=60)$; however, when considering only the results at $37^{\circ} \mathrm{C}$ and under natural water conditions, the influence was apparent (K-W: $\mathrm{p}<0.01, \mathrm{n}=15)$. When only looking at $\mathrm{S} 3$ but otherwise considering all incubation conditions, the effect of the $\mathrm{NH}_{4}^{+}$content was also highly significant ( $\mathrm{M}-\mathrm{W}$, for $\mathrm{S} 3$ : two-sided $\mathrm{p}<0.01, \mathrm{n}=12$ ). No significant influence could be found regarding the water content $(n=60)$, however, the water content had a significantly influence on the PoMO values at $37^{\circ} \mathrm{C}$ and when $\mathrm{NH}_{4}^{+}$was added (K-W: $\left.\mathrm{p}<0.01, \mathrm{n}=15\right)$.

\section{Discussion}

Generally speaking, enzyme activities per gram of DW increased with soil age as shown in Figure 1A. Enzyme activities per gram of SOM, on the other hand, did not increase with soil age but reached its maximum in the 35 (S1A) and 80 (S2) years old soils as shown in Figure 1B. This indicates that the physiologically active, highly reproductive fraction of soil microorganisms (r-strategists) decreases in soils older than 80 years, possibly because of a more restricted supply of readily available nutrients; a higher evenness of species (Sigler et al., 2002); increasing influence of root exudates, plant litter, and root morphology (Berg and Smalla 2009); and a higher SOM content (Table 1) in general. This shift from $\mathrm{r}$ - to $\mathrm{k}$-strategists probably occurs between soil aged 80 (S2) and 150 (S2A) years as a drop in microbial activity could be observed in soil S2A (Figure 1A). In addition, the nitrate content was highest in soil S2A (middle-aged soil) possibly because of a reduced nitrogen immobilization into microbial biomass (Table 1). However, the peak in nitrate content in S2A could have several other (combined) reasons such as an increased nitrate uptake by plants in soil S3 (oldest soil) and/or an overall increase in nitrification activity with soil age. As the nitrification activity was not assessed in this study, this remains to be speculative. At another glacier foreland site in the Austrian alps, it was shown that the percentage of recalcitrant carbon decreases with soil age, from 3- to 145-year-old soils showing that the first colonizers use a more ancient, recalcitrant carbon pool, whereas microbial communities in more developed (>50-year-old) soils use more easily available carbon compounds deriving from plants (Bardgett et al., 2007). These results are very interesting and, in general, not contradictory to the results at the Rotmoos glacier foreland because the 


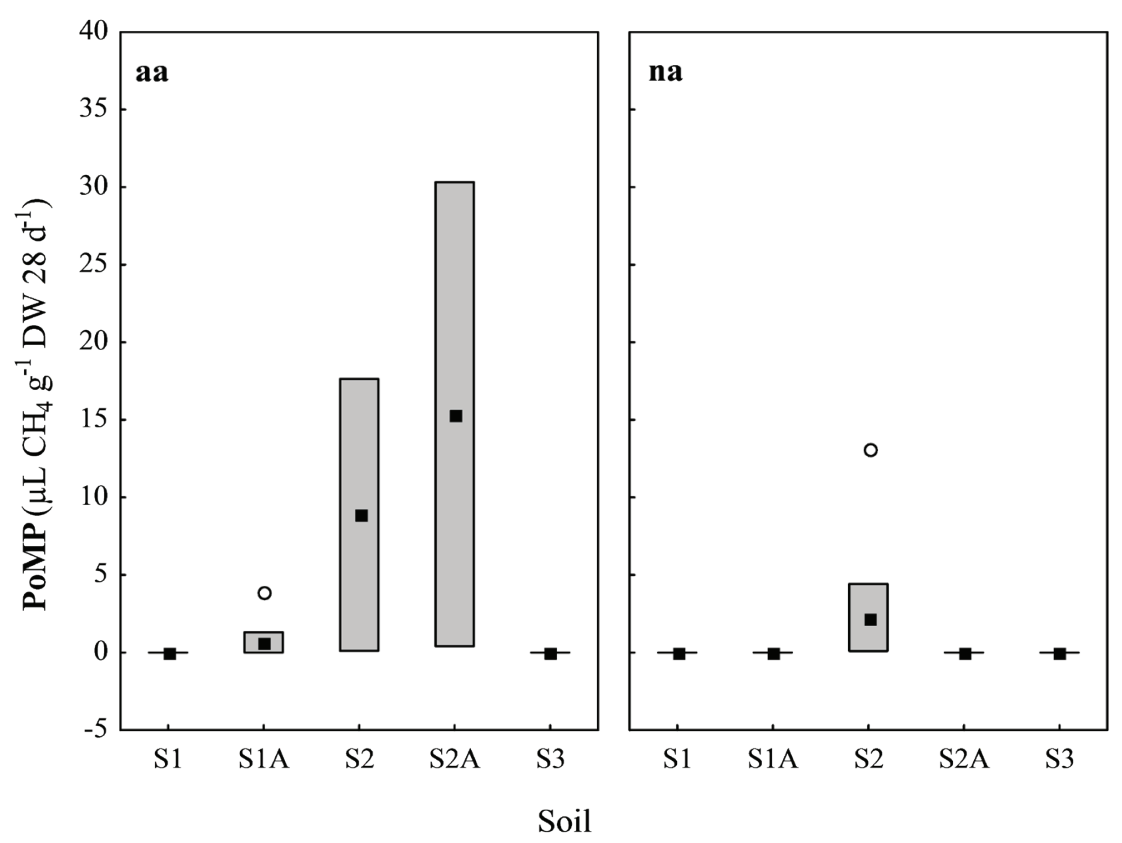

Figure 2. PoMP data of soil S1-S3 under water-saturated conditions, with ammonium added (aa) or with a natural ammonium content (na) at $10^{\circ} \mathrm{C}$ and $37^{\circ} \mathrm{C}(\mathrm{n}=6)$. Boxes represent mean values \pm standard error, black squares represent means, and circles represent outliers.

Abbildung 2. PoMP Daten für Boden S1 bis S3 unter wassergesättigten Verhältnissen, mit Ammoniumzugabe (aa) oder unter natürlichem Ammoniumgehalt (na) bei $10^{\circ} \mathrm{C}$ und $37^{\circ} \mathrm{C}(\mathrm{n}=6)$. Die Boxen repräsentieren den jeweiligen Mittelwert \pm Standardfehler, die schwarzen Quadrate geben Mittelwerte, die Kreise Ausreißer an.

highest enzyme activities per gram of SOM were found in the 35- and 80-year-old soils (Figure 1B). However, these previous findings are difficult to compare with our results because of various reasons. First, information on soils older than 145 years is missing. Second, the total SOM content of each soil is not mentioned. Third, the chemical composition of the SOM content of the Rotmoos site was not measured. Nonetheless, relating microbial activities to the respective SOM content could be an additional, fast, and cheap method to get a first overview of the (relative) metabolic situation of soils along a chronosequence.

Owing to the PoMP and PoMO results, this study confirms that methanogenic archaea and methanotrophic microorganisms, responsible for the biological methane production and oxidation, respectively, are present and active in the Rotmoos glacier forefield (Hofmann et al., 2013). The methanogens, although thriving in a rather cold environment, prefer mesophilic to psychrophilic conditions at this site, whereas methane oxidation was highest at $10^{\circ} \mathrm{C}$. Previous studies showed that methanogens of the Rotmoos glacier forefield can be active even at $50^{\circ} \mathrm{C}$, although rates were higher at $37^{\circ} \mathrm{C}$ (Hofmann et al., 2013). As one of the objectives was to assess the potential and, therefore, maximum methane production and oxidation, we chose a temperature of $37^{\circ} \mathrm{C}$ even though this seldom reflects in situ temperature conditions at the study site. However, the use of optimal (temperature) conditions and a standardized procedure allow the comparison of the results from soils with different soil characteristics — a strategy that has been accepted for other soil activity measurements for a long time (Schinner et al., 1996).

Soil S2 and S2A (middle-aged soils) provide more favorable conditions for methane production than soil S3 (oldest soil). Owing to the high turnover rates in soil S2 and S2A (Table 1), more molecules such as $\mathrm{CO}_{2}+\mathrm{H}_{2}$, needed for biological methane production, are provided. The higher activity of aerobic microorganisms may also lead to more anoxic conditions. The neutral $\mathrm{pH}$ in $\mathrm{S} 2$ and $\mathrm{S} 2 \mathrm{~A}$ is more suitable for methanogenic archaea than the slightly acidic conditions in soil S3 (Angelidaki and Ahring, 1994; Angelidaki and Sanders, 2004). Furthermore, archaea, to which methanogens belong, are known to be able to survive extreme conditions (e.g., rapid temperature changes) that are more common in undeveloped soils; therefore, they might have an advantage over many bacteria in these habitats. This assumption is in accordance with previous 


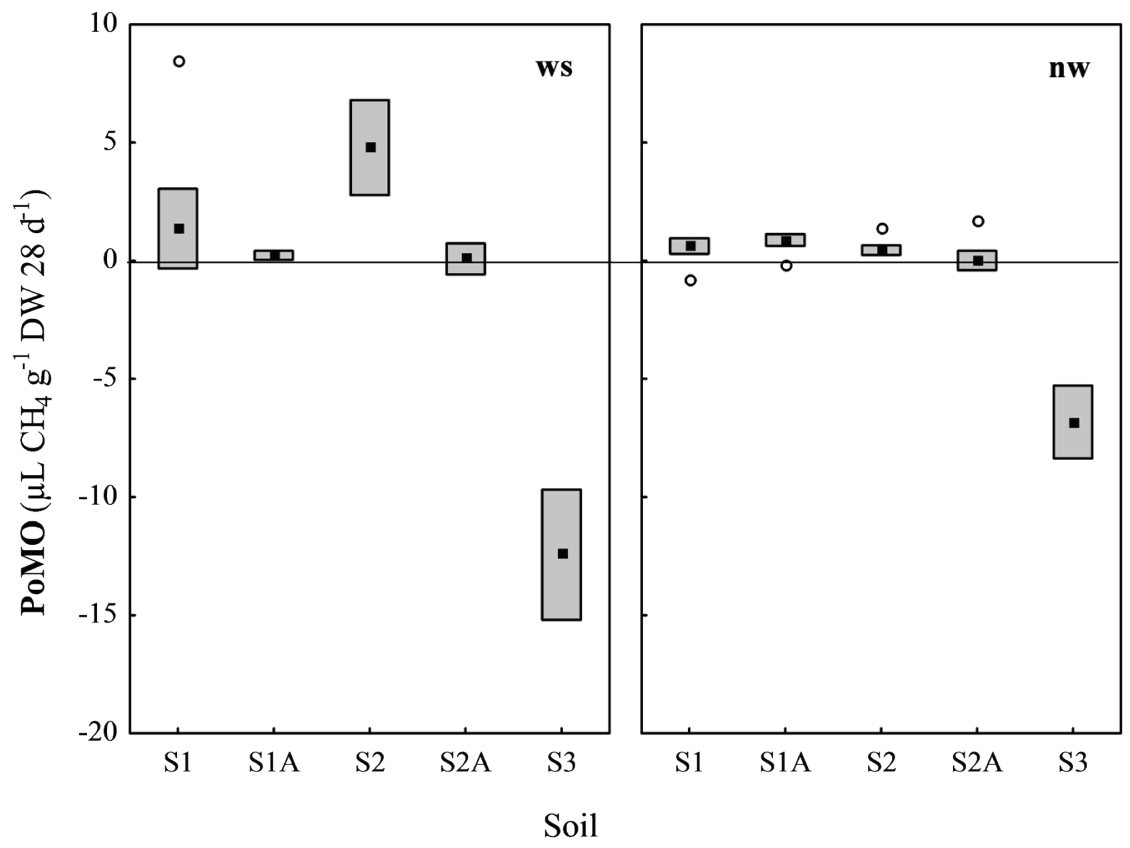

Figure 3. PoMO data of soil S1-S3with a natural ammonium content under water-saturated (ws) or natural water content (nw) conditions at $10^{\circ} \mathrm{C}$ and $37^{\circ} \mathrm{C}(n=6)$. Boxes represent mean values \pm standard error, black squares represent means, and circles represent outliers.

Abbildung 3. PoMO Daten für Boden S1-S3 unter natürlichem Ammoniumgehalt und unter wassergesättigten Verhältnissen (ws) bzw. bei natürlichem Wassergehalt $(\mathrm{nw})$ bei $10^{\circ} \mathrm{C}$ und $37^{\circ} \mathrm{C}(\mathrm{n}=6)$. Die Boxen repräsentieren den jeweiligen Mittelwert \pm Standardfehler, die schwarzen Quadrate geben Mittelwerte, die Kreise Ausreißer an.

studies at the site, which showed a significantly higher archaeal abundance in soil S2 $\left(4 \times 10^{7}\right.$ gene copies per gram of dry soil $)$ than in soil $S 1\left(2 \times 10^{5}\right.$ gene copies per gram of dry soil) or $\mathrm{S} 3\left(7 \times 10^{6}\right.$ gene copies per gram of dry soil $)$ (Hofmann et al., 2013). However, the big differences in PoMP between the parallels of soil S2 and S2A indicate an all or nothing principle and that methanogens are very heterogeneously distributed in the soil and thus need ecological micro niches to survive (Peters and Conrad, 1995; Timonen and Bomberg, 2009; Prem et al., 2014). Choosing the appropriate $\mathrm{NH}_{4}^{+}{ }_{4} \mathrm{~N}$ concentration for testing possible effects on methane production and oxidation was delicate because literature stated different inhibition levels especially for methanogens (Angelidaki and Ahring, 1993; Sung and Liu, 2003; Lins and Illmer, 2012). As the effect of ammonium on methanogens obviously depends on a variety of accompanying conditions (e.g., $\mathrm{pH}$, acclimation pre-phase (Sung and Liu, 2003)) and as we wanted to see a clear physiological responds but not necessarily a complete inhibition, we chose an ammonium addition of $3.5 \mathrm{~g}$ of $\mathrm{NH}_{4}^{+}-\mathrm{N}$ per liter of soil water-corresponding to about $200-900 \mu \mathrm{g}$ of $\mathrm{NH}_{4}^{+}-\mathrm{N}$ per gram of dry soil—which turned out to be just fine for our approach. This is based on previous fermenter sludge experiments including ammonium additions of up to $10.1 \mathrm{~g}$ of $\mathrm{NH}_{4}^{+}-\mathrm{N} \mathrm{L}^{-1}$ (Lins and Illmer, 2012). The ammonium addition had a significantly negative effect on PoMO in soil S3 (Figure 4). This was not statistically significant over all soils/variants as the effect of ammonium also depends on other (incubation) conditions. The negative effect of ammonium on methanotrophic species could also be shown in other studies (Cochran et al., 1995). Ammonium can be oxidized by the enzyme methane monooxygenase and can outcompete methane (Le Bodelier, 2011). The ability to oxidize ammonium and the sensitivity to ammonium, however, can vary depending on the respective methanotroph (Nyerges and Stein, 2009). On the other hand, the increased ammonium content in soil S2 and S2A (middle-aged soils) could have promoted PoMP (Figure 2) possibly because methanogens did not need to fix nitrogen themselves, used the easily available ammonium instead, and, therefore, saved energy for other processes (Leigh, 2000; Le Bodelier, 2011).

PoMP only occurred under water-saturated conditions, thus corresponding well with previous PoMP investigations 


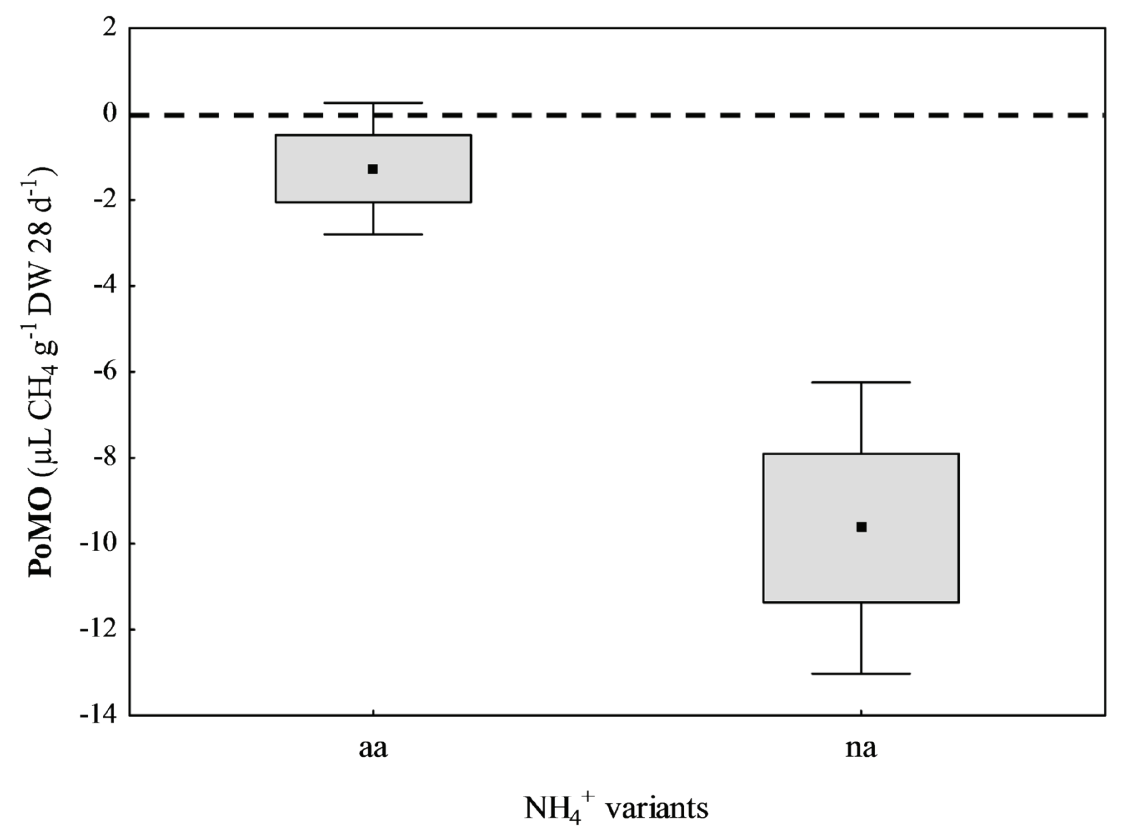

Figure 4. Potential methane oxidation of soil S3 with ammonium added (aa) and with natural ammonium content (na), including all water and temperature variants $(n=12)$. Boxes represent mean values \pm standard error, black squares represent means, and whiskers represent mean values $\pm 1.96 *$ standard error. The Mann-Whitney U test $(\mathrm{p}<0.05$, continuity correction) was applied which showed a highly significant difference between the two ammonium variants (aa, na) for soil S3: two-sided $p<0.01, \mathrm{Z}$-adjusted $=3.67$.

Abbildung 4. Potentielle Methanoxidation von Boden S3 bei Ammoniumzugabe (aa) bzw. unter natürlichem Ammoniumgehalt (na). Die BoxPlots beinhaltet alle Wasser- und Temperaturvarianten $(n=12)$. Die Boxen repräsentieren den jeweiligen Mittelwert \pm Standardfehler, schwarze Quadrate geben die Mittelwerte, Whiskers geben die Mittelwerte $\pm 1.96 *$ Standardfehler an. Der Mann-Whitney U test ( $p<0.05$, Kontinuitätskorrektur) zeigt einen hochsignifikanten Unterschied zwischen den beiden Ammoniumvarianten (aa, na) für den Boden S3: p (zwei-seitig) < 0.01, $\mathrm{Z}$ angepasst $=3.67$.

(Praeg et al., 2014; Prem et al., 2014). Besides, a high water content has a positive influence on nutrient supply and a negative one on the redox potential (Høj et al., 2006). Even though our laboratory-scale PoMP measurements were not suitable to simulate in situ conditions, water saturation was proven to be an important factor for the investigated soils, especially when the snow cover starts to melt in spring and early summer. Solar radiation can, furthermore, lead to higher soil temperature levels at this time of the year.

Previous in situ net methane emission measurements in the Rotmoos valley (Koch et al., 2007) showed that a welldeveloped meadow soil next to S3 (oldest soil) also functioned as a methane sink at least during snow-free periods. Multiple linear regression analysis for all diurnal measurements at the meadow site (snow-free periods) showed that the water-filled pore space had a positive influence, whereas the temperature at a depth of $15 \mathrm{~cm}$ in soil had a negative influence on the methane oxidation, explaining 52\% of the methane uptake (Koch et al., 2007). These results correspond with our laboratory-scale PoMO approach because PoMO in S3 was stronger under water-saturated than under natural conditions and was also higher at $10^{\circ} \mathrm{C}$ than at $37^{\circ} \mathrm{C}$. Water-saturated conditions lead to a better nutrient availability, as already stated earlier, and also to a reduction in $\mathrm{O}_{2}$ availability. It is not clear whether there is enough $\mathrm{O}_{2}$ left in the liquid phase or methane oxidation occurs anaerobically. However, the role of AOM in upland soils is more or less unknown but possible because of previous discoveries in freshwater environments (Segarra et al., 2015; Zhu et al., 2015; Wang et al., 2017). AOM cannot be ruled out at the Rotmoos site because S3 does have a relatively high SOM pool (Table 1), harbors a variety of soil microorganisms (see enzyme activities per gram of DW vs. enzyme activities per gram of SOM), and is water saturated at least in spring. This remains to be studied more profoundly. However, water saturation had the opposite effect on the less-developed soils. In the PoMO approach, soil S1 and S2 even showed a methane production 
under water-saturated conditions (Figure 3). The effect of ammonium addition and water saturation on the microorganisms in younger soils (S1-S2A) is quite contrary to the effect on microorganisms in soil S3 (Figures 2 and 3). By including these incubation variations in the PoMP and PoMO approaches, the differences in (potential) methane production and oxidation of the soils along the chronosequence could even be promoted.

\section{Conclusions}

In conclusion, our abiotic and enzyme activity measurements showed that the middle-aged soils, S2 and S2A, provided better conditions ( $\mathrm{pH}$ and nutrients) for PoMP than younger/older soils. Besides, the high turnover rates in these soils may have intensified anoxic conditions, making the habitat more suitable for methanogenic archaea. PoMO, on the other hand, could only be detected in the oldest soil and was, to our surprise, highest under watersaturated thus $\mathrm{O}_{2}$ restricted conditions. Many abiotic and biotic factors can influence the abundance and activity of microorganisms engaged in the methane cycle, which has been confirmed by the present study. Several models predicted a volume loss of glacier ice of about 25-48\% between 2010 and 2100 (Hock and Huss, 2015). This means that large areas of newly released raw soil could be colonized by methanogenic archaea and/or methanotrophs that could potentially release or consume methane. However, the interactive effects of the factors responsible for (net) methane production or oxidation are not thoroughly understood so far but are an important part to estimate the feedback of glacier retreat on further climate changesthus more investigations are urgently needed.

\section{Acknowledgments}

We thank Sieglinde Farbmacher and Philipp Lins for the soil sampling. We also thank Mira Mutschlechner for the constructive feedback. This publication was supported by the doctoral grant of the Vizerektorat für Forschung, Universität Innsbruck.

\section{References}

Angel, R., Matthies, D. and R. Conrad (2011): Activation of methanogenesis in arid biological soil crusts despite the presence of oxygen. PLoS One 6, e20453.

Angelidaki, I. and B. Ahring (1994): Anaerobic thermophilic digestion of manure at different ammonia loads: Effect of temperature. Water Research 28, 727-731.

Angelidaki, I. and B.K. Ahring (1993): Thermophilic anaerobic digestion of livestock waste. The effect of ammonia. Applied Microbiology and Biotechnology 38, 560-564.

Angelidaki, I. and W. Sanders (2004): Assessment of the anaerobic biodegradability of macropollutants. Re/ Views in Environmental Science \& Bio/Technology 3, 117-129.

Aronson, E.L., Vann, D.R. and B.R. Helliker (2012): Methane flux response to nitrogen amendment in an upland pine forest soil and riparian zone. Journal of Geophysical Research: Biogeosciences 117, G03012.

Bárcena, T.G., Finster, K.W. and J.C. Yde (2011): Spatial Patterns of Soil Development, Methane Oxidation, and Methanotrophic Diversity along a Receding Glacier Forefield, Southeast Greenland. Arctic, Antarctic, and Alpine Research 43, 178-188.

Bárcena, T.G., Yde, J.C. and K.W. Finster (2010): Methane flux and high-affinity methanotrophic diversity along the chronosequence of a receding glacier in Greenland. Annals of Glaciology 51, 23-31.

Bardgett, R.D., Richter, A., Bol, R., Garnett, M.H., Bäumler, R., Xu, X., Lopez-Capel, E., Manning, D.A.C., Hobbs, P.J. and I.R. Hartley (2007): Heterotrophic microbial communities use ancient carbon following glacial retreat. Biology Letters 3, 487-490.

Berg, G. and K. Smalla (2009): Plant species and soil type cooperatively shape the structure and function of microbial communities in the rhizosphere. FEMS Microbiology Ecology 68, 1-13.

Blodau, C. and M. Deppe (2012): Humic acid addition lowers methane release in peats of the Mer Bleue bog, Canada. Soil Biology and Biochemistry 52, 96-98.

Boetius, A., Ravenschlag, K., Schubert, C.J., Rickert, D., Widdel, F., Gieseke, A., Amann, R., Jørgensen, B.B., Witte, U. and O. Pfannkuche (2000): A marine microbial consortium apparently mediating anaerobic oxidation of methane. Nature 407, 623.

Bohn, S., Brunke, P., Gebert, J. and J. Jager (2011): Improving the aeration of critical fine-grained landfill top 
cover material by vegetation to increase the microbial methane oxidation efficiency. Waste Management 31, 854-863.

Bomberg, M., Montonen, L. and S. Timonen (2010): Anaerobic Eury- and Crenarchaeota inhabit ectomycorrhizas of boreal forest Scots pine. European Journal of Soil Biology 46, 356-364.

Brankatschk, R., Töwe, S., Kleineidam, K., Schloter, M. and J. Zeyer (2011): Abundances and potential activities of nitrogen cycling microbial communities along a chronosequence of a glacier forefield. The ISME Journal 5, 1025-1037.

Chiri, E., Nauer, P.A., Henneberger, R., Zeyer, J. and M.H. Schroth (2015): Soil-methane sink increases with soil age in forefields of Alpine glaciers. Soil Biology and Biochemistry 84, 83-95.

Cochran, V.L., Schlentner, S.F. and A.R. Mosier (1995): $\mathrm{CH}_{4}$ and $\mathrm{N}_{2} \mathrm{O}$ flux in subarctic agricultural soils. In: Lal, R., Kimble, J., Levine, E. and B.A. Stewart (Eds.): Soil Management and Greenhouse Effect. CRC Press Inc., Boca Raton FL, pp. 179-186.

Garland, J.L., Cook, K.L., Adams, J.L. and L. Kerkhof (2001): Culturability as an indicator of succession in microbial communities. Microbial Ecology 42, 150-158.

Göransson, H., Venterink, H.O. and E. Bååth (2011): Soil bacterial growth and nutrient limitation along a chronosequence from a glacier forefield. Soil Biology and Biochemistry 43, 1333-1340.

Hinrichs, K.-U. and A. Boetius (2003): The anaerobic oxidation of methane: New insights in microbial ecology and biogeochemistry. In: Wefer, G., Billet, D., Hebbeln, D., Jorgensen, B.B., Schlüter, M. and T. Weering (Eds.): Ocean margin systems. Springer, Berlin, Heidelberg, pp. 457-477.

Hock, R. and M. Huss (2015): A new model for global glacier change and sea-level rise. Frontiers in Earth Science 3, 1-22.

Hodkinson, I.D., Coulson, S.J. and N.R. Webb (2003): Community assembly along proglacial chronosequences in the high Arctic: vegetation and soil development in north-west Svalbard. Journal of Ecology 91, 651-663.

Hodkinson, I.D., Webb, N.R. and S.J. Coulson (2002): Primary community assembly on land-the missing stages: why are the heterotrophic organisms always there first? Journal of Ecology 90, 569-577.

Hofmann, K., Praeg, N., Mutschlechner, M., Wagner, A.O. and P. Illmer (2016): Abundance and potential metabolic activity of methanogens in well-aerated forest and grassland soils of an alpine region. FEMS Microbiology Ecology 92, fiv171.

Hofmann, K., Reitschuler, C. and P. Illmer (2013): Aerobic and anaerobic microbial activities in the foreland of a receding glacier. Soil Biology and Biochemistry 57, 418-426.

Høj, L., Rusten, M., Haugen, L.E., Olsen, R.A. and V.L. Torsvik (2006): Effects of water regime on archaeal community composition in Arctic soils. Environmental Microbiology 8, 984-996.

Kaufmann, R. (2001): Invertebrate succession on an alpine glacier foreland. Ecology 82, 2261-2278.

Knief, C., Lipski, A. and P.F. Dunfield (2003): Diversity and Activity of Methanotrophic Bacteria in Different Upland Soils. Applied and Environmental Microbiology 69, 6703-6714.

Koch, O., Tscherko, D. and E. Kandeler (2007): Seasonal and diurnal net methane emissions from organic soils of the Eastern Alps, Austria: effects of soil temperature, water balance, and plant biomass. Arctic, Antarctic, and Alpine Research 39, 438-448.

Küsel, K., Wagner, C. and H.L. Drake (1999): Enumeration and metabolic product profiles of the anaerobic microflora in the mineral soil and litter of a beech forest. FEMS Microbiology Ecology 29, 91-103.

Le Bodelier, P. (2011): Interactions between nitrogenous fertilizers and methane cycling in wetland and upland soils. Current Opinion in Environmental Sustainability 3, 379-388.

Le Mer, J. and P. Roger (2001): Production, oxidation, emission and consumption of methane by soils: a review. European Journal of Soil Biology 37, 25-50.

Leigh, J.A. (2000): Nitrogen fixation in methanogens. The archaeal perspective. Current Issues in Molecular Biology 2, 125-131.

Lins, P. and P. Illmer (2012): Effects of volatile fatty acids, ammonium and agitation on thermophilic methane production from biogas plant sludge in lab-scale experiments. Folia Microbiologica 57, 313-316.

Mapelli, F., Marasco, R., Rizzi, A., Baldi, F., Ventura, S., Daffonchio, D. and S. Borin (2011): Bacterial communities involved in soil formation and plant establishment triggered by pyrite bioweathering on Arctic moraines. Microbial Ecology 61, 438-447.

Mutschlechner, M., Praeg, N. and P. Illmer (2018): The influence of cattle grazing on methane fluxes and engaged microbial communities in alpine forest soils. FEMS Microbiology Ecology 94, fiy019. 
Nicol, G.W., Tscherko, D., Embley, T.M. and J.I. Prosser (2005): Primary succession of soil Crenarchaeota across a receding glacier foreland. Environmental Microbiology 7, 337-347.

Nyerges, G. and L.Y. Stein (2009): Ammonia cometabolism and product inhibition vary considerably among species of methanotrophic bacteria. FEMS Microbiology Letters 297, 131-136.

Orphan, V.J., House, C.H., Hinrichs, K.-U., McKeegan, K.D. and E.F. DeLong (2002): Multiple archaeal groups mediate methane oxidation in anoxic cold seep sediments. Proceedings of the National Academy of Sciences 99, 7663-7668.

Peters, V. and R. Conrad (1995): Methanogenic and other strictly anaerobic bacteria in desert soil and other oxic soils. Applied and Environmental Microbiology 61, 1673-1676.

Praeg, N., Wagner, A.O. and P. Illmer (2014): Effects of fertilisation, temperature and water content on microbial properties and methane production and methane oxidation in subalpine soils. European Journal of Soil Biology 65, 96-106.

Praeg, N., Wagner, A.O. and P. Illmer (2017): Plant species, temperature, and bedrock affect net methane flux out of grassland and forest soils. Plant and Soil 410, 193-206.

Prem, E.M., Reitschuler, C. and P. Illmer (2014): Livestock grazing on alpine soils causes changes in abiotic and biotic soil properties and thus in abundance and activity of microorganisms engaged in the methane cycle. European Journal of Soil Biology 62, 22-29.

Raghoebarsing, A.A., Pol, A., van de Pas-Schoonen, K.T., Smolders, A.J.P., Ettwig, K.F., Rijpstra, W.I.C., Schouten, S., Sinninghe Damsté, J.S., Op den Camp, H.J.M., Jeten, M.S.M. and M. Strous (2006): A microbial consortium couples anaerobic methane oxidation to denitrification. Nature 440, 918-921.

Schinner, F., Oehlinger, R., Kandeler, E. and R. Margesin (Hg.) (1996): Methods in Soil Biology. Springer, Heidelberg.

Schwienbacher, E. and E.-M. Koch (2010): Die Böden eines alpinen Gletschertales. In: Koch, E.-M. and B. Erschbamer (Eds.): Glaziale und periglaziale Lebensräume im Raum Obergurgl. Innsbruck University Press, Innsbruck, pp. 93-119.

Segarra, K.E.A., Schubotz, F., Samarkin, V., Yoshinaga, M.Y., Hinrichs, K.-U. and S.B. Joye (2015): High rates of anaerobic methane oxidation in freshwater wetlands reduce potential atmospheric methane emissions. Nature Communications 6, 7477.

Sigler, W.V., Crivii, S. and J. Zeyer (2002): Bacterial succession in glacial forefield soils characterized by community structure, activity and opportunistic growth dynamics. Microbial Ecology 44, 306-316.

Sivan, O., Adler, M., Pearson, A., Gelman, F., Bar-Or, I., John, S.G. and W. Eckert (2011): Geochemical evidence for iron-mediated anaerobic oxidation of methane. Limnology and Oceanography 56, 1536-1544.

Stibal, M., Wadham, J.L., Lis, G.P., Telling, J., Pancost, R.D., Dubnick, A., Sharp, M.J., Lawson, E.C., Butler, C.E.H. and F. Hasan (2012): Methanogenic potential of Arctic and Antarctic subglacial environments with contrasting organic carbon sources. Global Change Biology 18, 3332-3345.

Sung, S. and T. Liu (2003): Ammonia inhibition on thermophilic anaerobic digestion. Chemosphere 53, 43-52.

Timonen, S. and M. Bomberg (2009): Archaea in dry soil environments. Phytochemistry Reviews 8, 505-518.

Tscherko, D., Hammesfahr, U., Marx, M.-C. and E. Kandeler (2004): Shifts in rhizosphere microbial communities and enzyme activity of Poa alpina across an alpine chronosequence. Soil Biology and Biochemistry 36, 1685-1698.

Tscherko, D., Rustemeier, J., Richter, A., Wanek, W. and E. Kandeler (2003): Functional diversity of the soil microflora in primary succession across two glacier forelands in the Central Alps. European Journal of Soil Science 54, 685-696.

Ulrich, S., Tischer, S., Hofmann, B. and O. Christen (2010): Biological soil properties in a long-term tillage trial in Germany. Journal of Plant Nutrition and Soil Science 173, 483-489.

Wadham, J.L., Tranter, M., Tulaczyk, S. and M. Sharp (2008): Subglacial methanogenesis: a potential climatic amplifier? Global Biogeochemical Cycles 22, GB2021.

Wagner, A.O., Gstrauntaler, G. and P. Illmer (2010): Utilisation of single added fatty acids by consortia of digester sludge in batch culture. Waste Management 30, 1822-1827.

Wang, Y., Wang, D., Yang, Q., Zeng, G. and X. Li (2017): Wastewater Opportunities for Denitrifying Anaerobic Methane Oxidation. Trends in biotechnology 35, 799802.

Zeng, J., Wang, X.-X., Lou, K., Eusufzai, M.K., Zhang, T., Lin, Q., Shi, Y.-W., Yang, H.-M. and Z.-Q. Li (2015): Primary succession of soil enzyme activity and heterotro- 
phic microbial communities along the chronosequence of Tianshan Mountains No. 1 Glacier, China. Antonie van Leeuwenhoek, International Journal of General and Molecular Microbiology 107, 453-466.

Zhu, G., Zhou, L., Wang, Y., Wang, S., Guo, J., Long, X.-E., Sun, X., Jiang, B., Hou, Q., Jetten, M.S. and C. Yin (2015): Biogeographical distribution of denitrifying anaerobic methane oxidizing bacteria in Chinese wetland ecosystems. Environmental Microbiology Reports 7, 128-138.
Zumsteg, A., Luster, J., Göransson, H., Smittenberg, R.H., Brunner, I., Bernasconi, S.M., Zeyer, J. and B. Frey (2012): Bacterial, archaeal and fungal succession in the forefield of a receding glacier. Microbial Ecology 63, 552-564. 